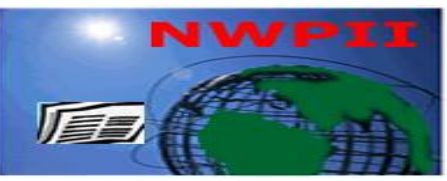

American Journal of Biomedical Sciences

ISSN: 1937-9080

nwpii.com/ajbms

\title{
Antimicrobial Activities of Chrysophyllum Albidum Leaves, Fruits and Seeds
}

\author{
GEORGE, Olajide A. ${ }^{\text {; }}$ ADENIPEKUN, Eyitayo O. ${ }^{2}$; FASOGBON, Samuel Ayobami³; \\ OPARANOZIE Jude A. ${ }^{4}$
}

1 Medical Laboratory Science Council of Nigeria, South-South Zonal office, Benin city, Nigeria

2 Department of Medical Laboratory Science, College of Medicine, University of Lagos, Nigeria

3,4 Public Health In-vitro Diagnostic Control Laboratory, Medical Laboratory Science Council of Nigeria, Yaba-

Lagos, Nigeria.

"Corresponding Author

George, Akintunde Olajide

Medical Laboratory Science Council of Nigeria

73, Murtala Mohammed Way, Benin City,

Edo State,

Nigeria.

E-mail: georgeolajide2016@gmail.com

Cell phone: +2348062234415

Received:31 January 2018; | Revised:01 March 2018; |Accepted: 20 March 2018

\begin{abstract}
Background: Chrysophyllum albidum is a medicinal plant that belongs to the Sapotaceae family. This study was carried out to determine the antimicrobial activities of the leaves, seeds and fruits of Chrysophyllum albidum.

Materials and Methods: The fruits, leaves and seeds of Chrysophyllum albidum were extracted with distilled water, Seaman's Schnapps, Methanol and Petroleum ether using cold extraction. These extracts were tested on various organisms. Antimicrobial activities of the various extracts were determined using the agar well diffusion technique to detect the Minimum Inhibitory Concentration (MIC).

Results and Discussion: Methicillin Resistant Staphylococcus aureus was inhibited by all the extracts at MIC between $32 \mu \mathrm{g} / \mathrm{ml}$ to $512 \mu \mathrm{g} / \mathrm{ml}$ except Seaman's Schnapps leaves and petroleum ether seed extract. The fruit extracts had a high antimicrobial activity against all the tested organisms. The extracts from Seaman's Schnapps had little activity while the aqueous extracts had MIC ranging from $64-512 \mu \mathrm{g} / \mathrm{ml}$ on most of the organisms tested. The statistical analysis of the extracts indicated P-value of 0.122 for Aqueous extracts, which was statistically insignificant compared to 0.003 for Methanolic extracts and 0.001 for Seaman's Schnapps extracts in the inhibition pattern of the extracts. Aqueous extracts showed more inhibitory activity than Methanolic and Seaman's Schnaps extracts.
\end{abstract}


Conclusion: Chrysophyllum albidum possess antimicrobial properties that can also be developed as antimicrobial for Multidrug resistant (MDR) organisms. Chyrsophyllum albidum is therefore recommended to be developed into new antimicrobials in readily available forms for use in Medical Microbiology Laboratory.

Keywords: Chrysophyllum albidum;Antimicrobial; MIC;Extracts.

\section{Introduction}

Chrysophyllum albidumis a medicinal plant that belong to the Sapotaceae family which has up to 800 species and make up almost half of the order Ericales ${ }^{[1]}$. Chrysophyllum is a genus of about 70 80 species of tropical trees growing rapidly to 10 $20 \mathrm{~m}$ or more in height. The generic name is derived from the Greek word Chrysos meaning 'gold' and Phyllos meaning 'leaf' ${ }^{[2]}$. The genus is native to tropical regions throughout the world, with the greatest number of species in northern South America. Chrysophyllum albidum is a dominant canopy tree of lowland mixed rain forest, sometimes riverine. It is widely distributed from West Africa to the Sudan with an eastern limit in Kakamega forest, Kenya [2]. Chrysophyllum albidum, is distributed throughout the Southern part of Nigeria where it is called 'Agbalumo' (Yoruba); 'Udara' (Igbo), while in the Northern Nigeria, it is called 'Khada'(Hausa) ${ }^{[3,4]}$. Tannins, flavonoids, terpenoids, protein, carbohydrates, and resins are the phytochemicals that have been reported in Chrysophyllum albidum ${ }^{[5]}$. Chrysophyllum albidum has antioxidant properties by scavenging free radicals, decreasing lipid peroxidation and increasing the endogenous blood antioxidant enzymes level ${ }^{[6]}$. The leaves of Chrysophyllum albidum was shown to reveal the presence of Alkaloids, Cardiac glycoside, Anthraquinones, Flavonoids, Terpenoids, and Steriods, which are useful substances that have medicinal and physiological activities. Vitamin D which is also believe it contain have also been linked with breast cancer ${ }^{[7-8]}$.

In recent times, there have been an increased antibiotic resistant strains of clinically important pathogens, which has led to the emergence of new bacterial strains that are multi-resistant $[9,10$, 11].Therefore, this has led to the search for more effective antimicrobial agents among materials of plant origin, with the aim of discovering potentially active ingredients that can serve as a source for the synthesis of new antimicrobial drugs ${ }^{[12]}$.

Medicinal plants use date back to several centuries in Africa and other regions of the world. It is about the first form of traditional medicine known and reported, and the practice is still popular ${ }^{[13,4]}$. The traditional preparations comprise medicinal plants, minerals and organic matter. Herbal drugs constitute only those traditional medicines which primarily use medicinal plant preparation for therapy ${ }^{[14]}$, however the search for agent to cure infectious disease began long before people were aware of the existence of microbes. These early attempts used natural substances, usually native plants or their extracts and many of these herbal remedies proved successful ${ }^{[15]}$. A number of studies have been done on the advantages or potency of herbs as cure for example, capsule Artimin from plant, and is a vegetarian capsule and dietary supplement that helps maintain the physiological well being of joints. It contains extracts of Salix alba (willow), Harpagophytum procumbens (Harpagus),Boswellia serrata (Boswelia), Malpighia punicifolia (Acerola) and Uncaria tormentosa (Uncaria) ${ }^{[16,17]}$. Therefore, more plants have to be checked for antimicrobial properties, so the need for this study.

Several workers have carried out the in vitro effects of extracts from plants with claimed medicinal use. Several experimental approaches are used. Usually water is used for extraction just as is used traditionally ${ }^{[18]}$. Other solvents used for extraction apart from water include chloroform, petroleum ether, ethanol, methanol, acetone etc. These extracts were tested against a wide range of microorganisms and their efficacy results well documented. It is not at all times however that such result confirms the claims of the tested herbs ${ }^{[19]}$.

There is paucity of data on the antimicrobial screening of Chrysophyllum albidum leaves, fruits 
and seed against multidrug resistant organisms, including Extended Spectrum Beta Lactamase producers and Methicilin Resistant Staphylococcus aureus. This study investigated the antimicrobial properties of Chrysophyllum albidum leaves, fruits and seed against multidrug resistant organisms.

\section{Materials and Methods}

\subsection{Area of Study}

This study was carried out at Department of Medical Microbiology, College of Medicine University of Lagos, Lagos State, Nigeria.

\subsection{Ethical Consideration}

Approval for this research work was obtained from the Research Ethics Committee of College of Medicine University of Lagos, Lagos State, Nigeria

\subsection{Collection and Preparation of Plant Extract}

The plants was identified and authenticated at the herbarium unit and Pharmacognosy Laboratory, College of Medicine, University of Lagos. The leaves and fruits of Chrysophyllum albidum (Agbalumo-Yoruba, Udara-Igbo and Khada-Hausa) were purchased at the Mushin Market in Lagos, Nigeria. The seed were obtained from the fruit pulp. (Plate 1 and 2)

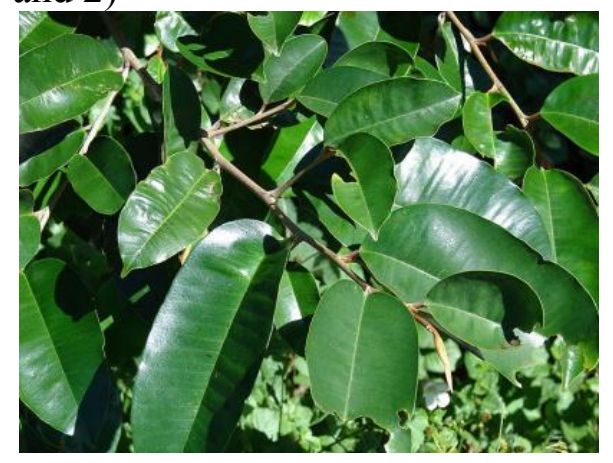

Plate 1 Chrysophyllum albidum Leaves

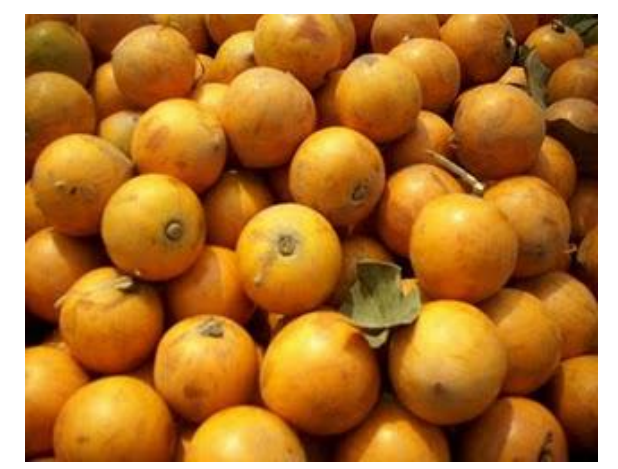

Plate 2 Chrysophyllum albidum Fruits

\subsection{Processing of Plant Materials}

The fresh leaves and fruits were properly washed in tap water and the seed were removed manually and washed in tap water. The plant leaves, fruits and seeds were allowed to dry for two weeks. The plants materials were pulverized into powder using an electric blender.

\subsection{Extraction of Plant Materials}

Distilled water, Seaman's Schnapps, Methanol and petroleum ether were used for the extraction of plant extracts. 100 grams of the dried and grounded leaves were suspended in $500 \mathrm{ml}$ of distilled water, Seaman's Schnapps and Methanol for extraction. 100 grams of the dried and grounded fruits were suspended in $500 \mathrm{ml}$ of Distilled water, Seaman's Schnapps and Methanol for extraction while 80 grams of the dried and grounded seed was soaked in distilled water and Petroleum ether. This was left to soak at room temperature for 72 hours with agitation at intervals. The extracts were filtered with Whatman filter paper No. $42(125 \mathrm{~mm})$. The filtrate were concentrated using the rotary evaporator at 450C.The concentrated extracts from each solvent were taken for lyophilization at the Department of Biochemistry, College of Medicine, University of Lagos. Each solid extract/ paste obtained after lyophilization was reconstituted in their respective solvents to obtain a stock solution of $512 \mu \mathrm{g} / \mathrm{ml}[25$, 26]. The stock solutions were stored in sterile capped bottles and labeled as follows:

1. Aqueous Leave Extract (ALE)

2. Aqueous Fruit Extract (AFE)

3. Aqueous Seed Extract (ASE)

4. Seaman's Schnapps Leave Extract (SSLE)

5. Seaman's Schnapps Fruit Extract (SSFE)

6. Methanolic Leave Extract (MLE)

7. Methanolic Fruit Extract (MFE)

8. Petroleum ether Seed Extract (PSE)

The stock solutions were stored at $40 \mathrm{C}-80 \mathrm{C}$.

\subsection{Test Organisms}

The organisms used were Shigella flexneri, Klebsiella pneumoniae (ESBL), Pseudomonas aeruginosa (MDR), Escherichia coli, Staphylococcus aureus(MRSA), Enterococcus faecalis and Candida albicans. The test organisms were obtained from the research laboratory of Medical Microbiology and Parasitology of College 
of Medicine, University of Lagos and Lagos University Teaching Hospital Laboratory.

\subsection{Control Organisms}

Control strains of Staphylococcus aureus ATTC 25923 and Escherichia coli ATTC 25922 were used and tested along with the test organisms as control.

\subsection{Identification of Microorganisms}

Microorganisms collected were authenticated for identification by Analytical Profile index 20E which is a standardized identification system for Enterobacteriaceae and other non-fastidious, Gramnegative rods.

The Analytical profile index 20E (API 20E, Biomerieux) strip consists of 20 micro tubes containing dehydrated substrates. These strips are inoculated with a $0.5 \mathrm{McF}$ arland standard bacterial suspension that reconstitutes the media. They were then incubated at $37 \mathrm{oC}$ overnight . The reactions are recorded and the identification is obtained by referring to the Analytical profile index identification software/flow chart.

\subsection{Reading the Strip}

Identification of the organisms is made by looking up the seven /nine digit profile in the Analytical Profile Index (API20E).The index is divided into two sections, the seven digit profiles read after 18-24hours of incubation and the nine digit profiles read after 36-48hours of incubation. The seven digit profile was used in this experiment. The flow chart was followed in the identification of the organisms.

\subsection{Phenotypic Detection of extended spectrum beta-lactamase}

The presence of Extended Spectrum BetaLactamase (ESBL) was detected by the double disc synergy test (DDST).A 0.5 McFarland Standard suspension of the test organism was inoculated on Mueller-Hinton agar. A disc containing $30 \mu \mathrm{g}$ Amoxicillin plus clavulanic acid disc was placed centrally on the plate (Plate 5).Disc containing Cefotaxime $(30 \mu \mathrm{g})$, Ceftazidime $(30 \mu \mathrm{g})$ and Ceftriaxone $(30 \mu \mathrm{g})$ were placed round the Amoxicillin plus Clavulanic acid disc at a distance of $15 \mathrm{~mm}{ }^{[10]}$. The plates were incubated overnight at
$37 \mathrm{oC}$ for 24 hours. Isolates that exhibited a distinct shape/size with an increased zone of inhibition towards Amoxicillin plus Clavulanate disc were considered as Extended spectrum beta-lactamase producers $^{[10]}$.

\subsection{Detection of Methicillin Resistant Staphylococcus aureus (MRSA)}

The presence of MRSA was detected using the modified Kirby-Bauer method (Bauer, et al.,1966).Isolated colonies from an 18hours culture was used to prepared a direct inoculum equivalent to a $0.5 \mathrm{McF}$ arland Standard. Suspension of the test organism was inoculated on Mueller Hinton Agar using a sterile swab. An Oxacillin disc containing $(1 \mu \mathrm{g})$ and Cefoxitin $(30 \mu \mathrm{g})$ were placed on the agar. The Mueller Hinton Agar on which Oxacillin discs was applied were supplemented with $2 \%$ Sodium Chloride $(\mathrm{NaCl})$ to enhance the detection of MRSA and incubated aerobically for 24 hours at $37 \mathrm{oC}$ while the one on which Cefoxitin was placed was not supplemented with sodium chloride $(\mathrm{NaCl})$ but incubated aerobically at $37 \mathrm{oC}$ for 24 hours(Plate 6)The strains were reported as sensitive, or resistant, to Oxacillin/ Cefoxitin with inhibition zone diameter equal or more than $13 \mathrm{~mm}$ and less than or equal to $10 \mathrm{~mm}$ respectively ${ }^{[27]}$.

\subsection{Standardization of Inoculum}

Test organisms were sub-cultured onto fresh plates of Mueller Hinton agar and Sabouraud Dextrose Agar for 18-24 hours at 37oC for bacteria and fungi respectively. Colonies from these were suspended in sterile normal saline to a turbidity matching 0.5 McFarland standard containing $1 \mathrm{x}$ $108 \mathrm{cfu} / \mathrm{ml}$ for bacteria and fungi respectively ${ }^{[25]}$.

\subsection{Antimicrobial Assay}

Suspension of the microorganisms were made in sterile normal saline and adjusted to 0.5 McFarland standards. The resulting suspension contains 1 x $108 \mathrm{cfu} / \mathrm{ml}$. Each labeled medium Plates were uniformly seeded with a test organism by means of sterile swab rolled in the suspension and streaked on the plate surface. Well of $5 \mathrm{~mm}$ in diameter and about $2 \mathrm{~cm}$ apart were punched in the culture media with sterile cork-borer. Then $10 \mu 1$ of the concentrations of the Chrysophyllum albidum extracts ranging from $4 \mu \mathrm{g} / \mathrm{ml}$ to $512 \mu \mathrm{g} / \mathrm{ml}$ were 
placed in each well ${ }^{[28,26]}$. Ciprofloxacin, Distilled water, Seaman's Schnapps, methanol and petroleum ether solvents were placed in a well on each plate seeded with test organisms as controls. Each plate was kept in the refrigerator at $40 \mathrm{C}$ for 1 hour to allow the extracts to diffuse into the culture medium while the immediate growth of the organism was stopped from taking place ${ }^{[25]}$. These plates were then incubated at $370 \mathrm{C}$ for 24 hours. The zones of inhibition around the wells were measured in millimeter.

\subsection{Reading of Results}

A ruler was placed across the well and zone of inhibition was measured in millimeter. This was recorded as positive bioactivity. Control strains of organism were set up and measured as well.

\subsection{Antifungal Assay}

Suspension of the Candida albicans were made in sterile normal saline and adjusted to 0.5 McFarland standards. The resulting suspension contains $1 \mathrm{x} 108 \mathrm{cfu} / \mathrm{ml}$. Each labeled medium Plates were uniformly seeded with the Candida albicans by means of sterile swab rolled in the suspension and streaked on the plate surface. Well of $5 \mathrm{~mm}$ in diameter and about $2 \mathrm{~cm}$ apart were punched in the culture media with sterile cork-borer. The concentrations of the extracts ranging from $4 \mu \mathrm{g} / \mathrm{ml}$ to $512 \mu \mathrm{g} / \mathrm{ml}$ were dropped in each well to fullness $[28,26]$. Each plate was kept in the refrigerator at $40 \mathrm{C}$ for 1 hour to allow the extracts to diffuse into the culture medium while the immediate growth of the organism was stopped from taking place. ${ }^{[25]}$.These plates are then incubated at $370 \mathrm{C}$ for 48 hours. The zones of inhibition around the wells were measured in millimeter.

\subsection{Determination of minimum inhibitory concentration (MIC)}

To measure the MIC values, various concentrations of the stock, $512 \mu \mathrm{g} / \mathrm{ml}, 256 \mu \mathrm{g} / \mathrm{ml}$, $128 \mu \mathrm{g} / \mathrm{ml}, 64 \mu \mathrm{g} / \mathrm{ml}, 32 \mu \mathrm{g} / \mathrm{ml}, 16 \mu \mathrm{g} / \mathrm{ml}, 8 \mu \mathrm{g} / \mathrm{ml}$, and $4 \mu \mathrm{g} / \mathrm{ml}$ were assayed against the test bacteria. The minimum inhibitory concentration was defined as the lowest concentration able to inhibit any visible bacterial growth on the culture plates ${ }^{[29,28,26]}$.

Table 1 Zone of inhibition ( $\mathrm{mm}$ ) of organisms to aqueous leave extract (ale) of chrysophyllum albidum

\begin{tabular}{|c|c|c|c|c|c|c|c|c|c|c|c|}
\hline \multirow[t]{2}{*}{ TEST ORGANISMS } & \multicolumn{11}{|c|}{ CONCENTRATION $(\mu \mathrm{g} / \mathrm{ml})$} \\
\hline & 512 & 256 & 128 & 64 & 32 & 16 & 8 & 4 & CIP & $\mathrm{H}_{2} \mathrm{O}$ & MIC \\
\hline S.aureus ATCC 25923 & 14 & 11 & 10 & - & - & - & - & - & 15 & - & 128 \\
\hline S. aureus & 18 & 17 & - & - & - & - & - & - & 15 & - & 256 \\
\hline S.aureus(MRSA) & 15 & 12 & - & - & - & - & - & - & - & - & 256 \\
\hline E.coli ATCC 25922 & 11 & 8 & - & - & - & - & - & - & 30 & - & 256 \\
\hline E.coli (ESBL) & 12 & 10 & - & - & - & - & - & - & 29 & - & 256 \\
\hline Shigella flexneri & 11 & 8 & - & - & - & - & - & - & - & - & 256 \\
\hline E.feacalis & 12 & 10 & - & - & - & - & - & - & - & - & 256 \\
\hline Klebsiella pneumonia & 15 & 10 & - & - & - & - & - & - & - & - & 256 \\
\hline $\begin{array}{l}\text { Pseudomonas } \\
\text { aeruginosa(MDR) }\end{array}$ & 16 & 8 & - & - & - & - & - & - & - & - & 256 \\
\hline Candida albicans & 10 & - & - & - & - & - & - & - & - & - & 512 \\
\hline
\end{tabular}

Key

$\mathrm{H}_{2} \mathrm{O}=$ Water

MRSA $=$ Methicillin resistant Staphylococcus aureus 


$\begin{aligned}- & =\text { No activity } \\ \text { CIP } & =\text { Ciprofloxacin control } \\ \text { MIC } & =\text { Minimum Inhibitory Concentration } \\ \text { ALE } & =\text { Aqueous leave extract. } \\ \text { MDR } & =\text { Multi drug resistance }\end{aligned}$

Table 2 Zone of inhibition (mm) of organisms to aqueous fruit extract (afe) of chrysophyllum albidum

\begin{tabular}{|l|l|l|l|l|l|l|l|l|l|l|l|}
\hline \multirow{2}{*}{ TEST ORGANISMS } & \multicolumn{6}{l|}{ CONCENTRATION $(\mu \mathrm{g} / \mathrm{ml})$} \\
\cline { 2 - 14 } & 512 & 256 & 128 & 64 & 32 & 16 & 8 & 4 & $\mathrm{CIP}$ & $\mathrm{H}_{2} 0$ & $\mathrm{MIC}$ \\
\hline S.aureus ATCC 25923 & 16 & 14 & - & - & - & - & - & - & 16 & - & 256 \\
\hline S. aureus & 31 & 24 & 20 & 11 & - & - & - & - & 24 & - & 64 \\
\hline S.aureus(MRSA) & 30 & 23 & 16 & 14 & - & - & - & - & 15 & - & 64 \\
\hline E.coli ATCC 25922 & - & - & - & - & - & - & - & - & 28 & - & - \\
\hline E.coli (ESBL) & - & - & - & - & - & - & - & - & 20 & - & - \\
\hline Shigella flexneri & - & - & - & - & - & - & - & - & - & - & - \\
\hline E.feacalis & - & - & - & - & - & - & - & - & - & - & - \\
\hline Klebsiella pneumonia & 16 & 10 & - & - & - & - & - & - & - & - & 256 \\
\hline $\begin{array}{l}\text { Pseudomonas } \\
\text { aeruginosa(MDR) }\end{array}$ & 15 & 13 & 11 & 10 & - & - & - & - & - & - & 64 \\
\hline Candida albicans & 14 & 13 & 8 & - & - & - & - & - & - & - & 128 \\
\hline
\end{tabular}

\section{Key}

$\mathrm{H}_{2} \mathrm{O}=$ Water

MRSA $=$ Methicillin resistant Staphylococcus aureus

$-\quad=$ No activity

CIP $=$ Ciprofloxacin control

MIC = Minimum Inhibitory Concentration

$\mathrm{AFE}=$ Aqueous fruit extract

MDR = Multi drug resistance

\section{Results}

The results in Table I showed that all the tested organisms were inhibited by the aqueous leave extracts of Chrysophyllum albidum with Minimum Inhibitory Concentration (MIC) ranging between of $128-512 \mu \mathrm{g} / \mathrm{ml}$. S. aureus ATCC 25923 had the lowest MIC.

Ciprofloxacin was used as control antibiotics for all tests carried out as well as the solvents used for extraction.
The aqueous fruit extract inhibited six organisms with MIC range between $64-256 \mu \mathrm{g} / \mathrm{ml}$ (Table2 and Plate 3).

Escherichia coli ATCC 25922, Shigella flexneri, ESBL Escherichia coli and Enterococcus faecalis were resistant to the aqueous fruit extract of Chrysophyllum albidum. Methicillin Resistant Staphylococcus aureus, Staphylococcus aureus and Pseudomonas aeruginosa had the lowest MIC of $64 \mu \mathrm{g} / \mathrm{ml}$ respectively (Table 2 ) 
The aqueous seed extract of Chrysophyllum albidum showed inhibition on all the organisms tested except Pseudomonas aeruginosa and Enterococcus faecalis which were resistant. The
MIC range is between $128-512 \mu \mathrm{g} / \mathrm{ml}$. Methicillin Resistant Staphylococcus aureus had the lowest MIC of $128 \mu \mathrm{g} / \mathrm{ml}$ (Table 3 ).

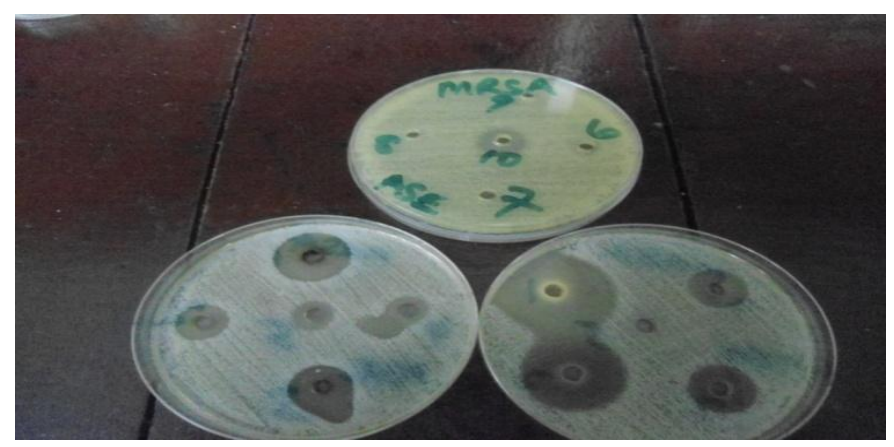

Plate 3 Showing the zone of inhibition of Methicillin Resistant Staphylococcus aureus to the aqueous leave, fruit and seed extracts of Chrysophyllum albidum

Table 3 Zone of inhibition ( $\mathrm{mm}$ ) of organisms to aqueous seed extract (ase) of chrysophyllum albidum

\begin{tabular}{|c|c|c|c|c|c|c|c|c|c|c|c|}
\hline \multirow[t]{2}{*}{ TEST ORGANISMS } & \multicolumn{11}{|c|}{ CONCENTRATION $(\mu \mathrm{g} / \mathrm{ml})$} \\
\hline & 512 & 256 & 128 & 64 & 32 & 16 & 8 & 4 & CIP & $\mathrm{H}_{2} \mathrm{O}$ & MIC \\
\hline S.aureus ATCC 25923 & 18 & 13 & - & - & - & - & - & - & 18 & - & 256 \\
\hline S. aureus & 16 & 15 & - & - & - & - & - & - & 24 & - & 256 \\
\hline S.aureus(MRSA) & 22 & 12 & 11 & - & - & - & - & - & 14 & - & 128 \\
\hline E.coli ATCC 25922 & 14 & - & - & - & - & - & - & - & 40 & - & 512 \\
\hline E.coli (ESBL) & 6 & - & - & - & - & - & - & - & 15 & - & 512 \\
\hline Shigella flexneri & 15 & 10 & - & - & - & - & - & - & 35 & - & 256 \\
\hline E.feacalis & - & - & - & - & - & - & - & - & - & - & - \\
\hline Klebsiella pneumonia & 13 & - & - & - & - & - & - & - & - & - & 512 \\
\hline $\begin{array}{l}\text { Pseudomonas } \\
\text { aeruginosa(MDR) }\end{array}$ & - & - & - & - & - & - & - & - & - & - & - \\
\hline Candida albicans & 16 & 12 & - & - & - & - & - & - & - & - & 256 \\
\hline
\end{tabular}

\section{Key}

$\mathrm{H}_{2} \mathrm{O}=$ Water

MRSA $=$ Methicillin resistant Staphylococcus aureus

- $\quad=$ No activity

CIP = Ciprofloxacin control

MIC = Minimum Inhibitory Concentration

$\mathrm{ASE}=$ Aqueous seed extract

MDR = Multi drug resistance 
The results in Table 4 showed that Pseudomonas aeruginosa had (MIC) of $64 \mu \mathrm{g} / \mathrm{ml}$ with the Seaman's Schnapps leaf extract (Plate 4).

Shigella flexneri was sensitive with MIC of $256 \mu \mathrm{g} / \mathrm{ml}$ while other organisms were resistant to the Seaman's Schnapps leaf extract (Table 4).

The Seaman's Schnapps fruit extract exhibited antimicrobial activity against all the organisms. The MIC range is between $32-512 \mu \mathrm{g} / \mathrm{ml}$. S.aureus (MRSA), E.coli (ESBL), Pseudomonas aeruginosa (MDR) and Candida albicans had MIC of $64 \mu \mathrm{g} / \mathrm{ml}$ respectively. The control strains S.aureus ATCC 25923, S.aureus, and E.faecalis had MIC of $512 \mu \mathrm{g} / \mathrm{ml}$. The lowest MIC was exhibited by Klebsiella pneumonia with MIC of $32 \mu \mathrm{g} / \mathrm{ml}$ (Table $5)$.

The methanolic leaf extract of Chrysophyllum albidum exhibited antimicrobial activities against S.aureus (MRSA), Pseudomonas aeruginosa and Shigella flexneri whichhad MIC of $512 \mu \mathrm{g} / \mathrm{ml}$ respectively (Table 6).

Table 4 Zones of inhibition ( $\mathrm{mm}$ ) of organisms to seaman's schnapps leaf extract (ssle) of chrysophyllum albidum

\begin{tabular}{|l|l|l|l|l|l|l|l|l|l|l|l|l|}
\hline \multirow{2}{*}{ TEST ORGANISMS } & \multicolumn{6}{|l|}{ CONCENTRATION $(\mu \mathrm{g} / \mathrm{ml})$} \\
\cline { 2 - 13 } & 512 & 256 & 128 & 64 & 32 & 16 & 8 & 4 & CIP & \multicolumn{2}{l|}{ SS } & MIC \\
\hline S.aureus ATCC 25923 & - & - & - & - & - & - & - & - & 20 & - & -- \\
\hline S. aureus & & - & - & - & - & - & - & - & - & 17 & - & - \\
\hline S.aureus (MRSA) & - & - & - & - & - & - & - & - & - & - & - \\
\hline E.coli ATCC 25922 & - & - & - & - & - & - & - & - & 31 & - & - \\
\hline E.coli (ESBL) & & - & - & - & - & - & - & - & - & - & - & - \\
\hline Shigella flexneri & 12 & 10 & - & - & - & - & - & - & 35 & - & 256 \\
\hline E.feacalis & - & - & - & - & - & - & - & - & 8 & - & - \\
\hline Klebsiella pneumonia & - & - & - & - & - & - & - & - & - & - & - \\
\hline $\begin{array}{l}\text { Pseudomonas } \\
\text { aeruginosa(MDR) }\end{array}$ & 15 & 13 & 16 & 15 & - & - & - & - & 20 & - & 64 \\
\hline Candida albicans & & & & & & & & & & & \\
\hline
\end{tabular}

\footnotetext{
Key

SS = Seaman's Schnapps

MRSA = Methicillin resistant Staphylococcus aureus

- $\quad=$ NO activity

CIP = Ciprofloxacin control

MIC = Minimum Inhibitory Concentration

MDR = Multi drug resistance
} 


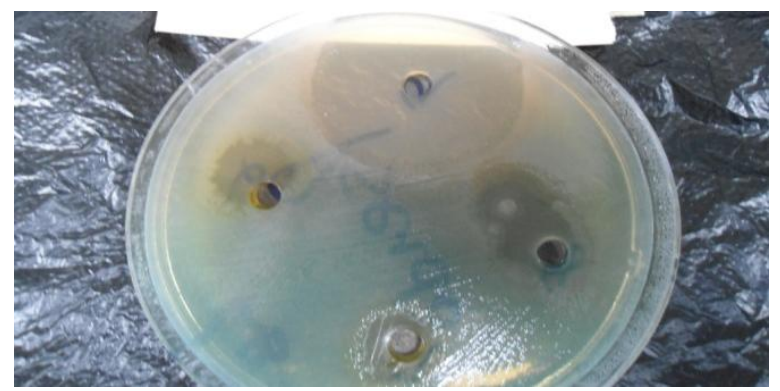

Plate 4 Showing the zone of inhibition of Pseudomonas aeruginosa to the Seaman's schnapps leave extracts of Chrysophyllum albidum

Table 5 Zones of inhibition (mm) of organisms to seaman's schnapps fruit extract (ssfe) of chrysophyllum albidum

\begin{tabular}{|l|l|l|l|l|l|l|l|l|l|l|l|l|}
\hline \multirow{2}{*}{ TEST ORGANISMS } & \multicolumn{6}{|l|}{ CONCENTRATION $(\mu \mathrm{g} / \mathrm{ml})$} \\
\cline { 2 - 12 } & 512 & 256 & 128 & 64 & 32 & 16 & 8 & 4 & CIP & \multicolumn{2}{l|}{ SS } & \multicolumn{2}{l|}{ MIC } \\
\hline S.aureus ATCC 25923 & 15 & - & - & - & - & - & - & - & 24 & - & 512 \\
\hline S. aureus & 16 & - & - & - & - & - & - & - & - & - & 512 \\
\hline S.aureus(MRSA) & 15 & 14 & 12 & 10 & - & - & - & - & - & - & 64 \\
\hline E.coli ATCC 25922 & 14 & 12 & 11 & - & - & - & - & - & 23 & 7 & 128 \\
\hline E.coli (ESBL) & 14 & 13 & 12 & 10 & - & - & - & - & 36 & - & 64 \\
\hline Shigella flexneri & 16 & 9 & 7 & - & - & - & - & - & 34 & - & 128 \\
\hline E.feacalis & 15 & - & - & - & - & - & - & - & 23 & - & 512 \\
\hline Klebsiella pneumonia & 15 & 10 & 9 & 7 & 6 & - & - & - & - & & 32 \\
\hline Pseudomonas & 17 & 16 & 14 & 11 & - & - & - & - & 32 & - & 64 \\
\hline aeruginosa(MDR) & & & & & & & & & & & \\
\hline Candida albicans & 13 & 12 & 10 & 9 & - & - & - & - & - & - & 64 \\
\hline
\end{tabular}

Key

$\mathrm{SS}=$ seaman's schnapps

MRSA = methicillin resistant Staphylococcus aureus

$-\quad=$ NO activity

CIP = Ciprofloxacin control

MIC = Minimum Inhibitory Concentration

MDR = Multi drug resistance 
The methanolic fruit extract exhibited antimicrobial activity against all the tested organisms with MIC range between $16-256 \mu \mathrm{g} / \mathrm{ml}$ of C.albidum.

Staphylococcus aureus had the lowest minimum inhibitory concentration of $16 \mathrm{mg} / \mathrm{ml}$. S.aureus (MRSA) and Shigella flexneri both had MIC of $32 \mu \mathrm{g} / \mathrm{ml}$. E.coli, E.faecalis, K.pneumoniaewere susceptible at MIC of $64 \mu \mathrm{g} / \mathrm{ml}$ respectively. E.coli ATCC 25922 and Pseudomonas aeruginosa both showed MIC of $128 \mu \mathrm{g} / \mathrm{ml}$ respectively. Staphylococcus aureus ATCC 25923 and Candida albicans showed MIC of $256 \mu \mathrm{g} / \mathrm{ml}$ (Table7).

Enterococcus faecalis with MIC of $8 \mu \mathrm{g} / \mathrm{ml}$ showed high sensitivity to the seed oil extract followed by Shigella flexneri with MIC of $64 \mu \mathrm{g} / \mathrm{ml}$. Other organisms were resistant to the seed oil extract. (Table 8)

Table 6 Zones of inhibition (mm) of organisms to methanolic leaf extract (mle) of chrysophyllum albidum

\begin{tabular}{|c|c|c|c|c|c|c|c|c|c|c|c|}
\hline \multirow[t]{2}{*}{ TEST ORGANISMS } & \multicolumn{11}{|c|}{ CONCENTRATION $(\mu \mathrm{g} / \mathrm{ml})$} \\
\hline & 512 & 256 & 128 & 64 & 32 & 16 & 8 & 4 & CIP & METH & MIC \\
\hline S.aureus ATCC 25923 & - & - & - & - & - & - & - & - & - & - & - \\
\hline S. aureus & - & - & - & - & - & - & - & - & 20 & - & - \\
\hline S.aureus(MRSA) & 6 & - & - & - & - & - & - & - & - & - & 512 \\
\hline E.coli ATCC 25922 & - & - & - & - & - & - & - & - & 14 & - & - \\
\hline E.coli (ESBL) & - & - & - & - & - & - & - & - & 35 & - & - \\
\hline Shigella flexneri & 8 & - & - & - & - & - & - & - & 17 & - & 512 \\
\hline E.feacalis & - & - & - & - & - & - & - & - & 18 & - & - \\
\hline Klebsiella pneumonia & - & - & - & - & - & - & - & - & - & - & - \\
\hline $\begin{array}{l}\text { Pseudomonas } \\
\text { aeruginosa(MDR) }\end{array}$ & 10 & - & - & - & - & - & - & - & 25 & 6 & 512 \\
\hline Candida albicans & - & - & - & - & - & - & - & - & - & - & - \\
\hline
\end{tabular}

Key

METH. = Methanol

MRSA = Methicillin resistant staphylococcus aureus

- $\quad=$ No activity

$\mathrm{CIP} \quad=$ Ciprofloxacin control

MIC $\quad$ Minimum Inhibitory Concentration

MDR = Multi drug resistance 
Table 7 Zones of inhibition (mm) of organisms to methanolic fruit extract (mfe) of chrysophyllum albidum

\begin{tabular}{|c|c|c|c|c|c|c|c|c|c|c|c|}
\hline \multirow[t]{2}{*}{ TEST ORGANISMS } & \multicolumn{11}{|c|}{ CONCENTRATION $(\mu \mathrm{g} / \mathrm{ml})$} \\
\hline & 512 & 256 & 128 & 64 & 32 & 16 & 8 & 4 & CIP & METH. & MIC \\
\hline S.aureus ATCC 25923 & 16 & 13 & - & - & - & - & - & - & 27 & - & 256 \\
\hline S. aureus & 22 & 20 & 16 & 10 & 8 & 7 & - & - & - & 10 & 16 \\
\hline S.aureus(MRSA) & 21 & 16 & 15 & 10 & 9 & - & - & - & - & - & 32 \\
\hline E.coli ATCC 25922 & 17 & 14 & 10 & - & - & - & - & - & 37 & - & 128 \\
\hline E.coli (ESBL) & 19 & 17 & 10 & 7 & - & - & - & - & 32 & - & 64 \\
\hline Shigella flexneri & 20 & 15 & 13 & 12 & 11 & - & - & - & 33 & - & 32 \\
\hline E.feacalis & 16 & 11 & 10 & 8 & - & - & - & - & 20 & - & 64 \\
\hline Klebsiella pneumonia & 15 & 14 & 11 & 10 & - & - & - & - & - & - & 64 \\
\hline Pseudomonas aeruginosa(MDR) & 14 & 13 & 8 & - & - & - & - & - & 25 & 7 & 128 \\
\hline Candida albicans & 12 & 10 & - & - & - & - & - & - & - & - & 256 \\
\hline
\end{tabular}

Key

METH. $=$ Methanol

MRSA = Methicillin resistant Staphylococcus aureus

$-\quad=$ No activity

CIP = Ciprofloxacin control

MIC = Minimum Inhibitory Concentration

MDR = Multi drug resistance

Table 8 Zones of inhibition ( $\mathrm{mm}$ ) of organisms to petroleum ether seed extract (pse) of chrysophyllum albidum

\begin{tabular}{|l|l|l|l|l|l|l|l|l|l|l|l|l|}
\hline \multirow{2}{*}{ TEST ORGANISMS } & \multicolumn{6}{l|}{ CONCENTRATION $(\mu \mathrm{g} / \mathrm{ml})$} \\
\cline { 2 - 14 } & 512 & 256 & 128 & 64 & 32 & 16 & 8 & 4 & CIP & \multicolumn{2}{l|}{ PET } & MIC \\
\hline S.aureus ATCC 25923 & - & - & - & - & - & - & - & - & 27 & - & - \\
\hline S. aureus & - & - & - & - & - & - & - & - & - & - & - \\
\hline S.aureus(MRSA) & - & - & - & - & - & - & - & - & - & - & - \\
\hline E.coli ATCC 25922 & - & - & - & - & - & - & - & - & 38 & - & - \\
\hline E.coli (ESBL) & - & - & - & - & - & - & - & - & - & 16 & - \\
\hline Shigella flexneri & 17 & 15 & 12 & 10 & - & - & - & - & 33 & - & 64 \\
\hline E.feacalis & 25 & 24 & 23 & 20 & 18 & 17 & 15 & - & 20 & - & 8 \\
\hline Klebsiella pneumonia & - & - & - & - & - & - & - & - & - & - & - \\
\hline Pseudomonas aeruginosa(MDR) & - & - & - & - & - & - & - & - & 37 & - & - \\
\hline Candida albicans & - & - & - & - & - & - & - & - & - & - & - \\
\hline
\end{tabular}


Key

PET. = Petroleum ether.

MRSA $=$ Methicillin resistant Staphylococcus aureus

- $\quad=$ No activity

CIP = Ciprofloxacin control

MIC = Minimum Inhibitory Concentration

MDR = Multi drug resistance

\section{Discussion}

The organisms used included Shigella flexneri, Klebsiella pneumoniae (ESBL), Pseudomonas aeruginosa (MDR- multi drug resistant), Escherichia coli, Staphylococcus aureus, Enterococcus faecalis, Methicilin Resistant Staphylococcus aureus, Escherichia coli(ATCC 25922), Staphylococcus aureus(ATCC 25923) and Candida albicans and these gave a wider range of comparison of antimicrobial properties among several bacteria unlike other medicinal plants studies where only four to six organisms were used $[20,22]$.

A research reported that water and methanolic extracts of Chrysophyllum albidum leaves used against Staphylococcus aureus, Escherichia coli, Salmonella typhi, and Shigella species suggested that water and methanolic extracts from the leaves may contain active agent(s), which make them susceptible to the tested organisms ${ }^{[20]}$. Another study reported also that ethanolic extract of Chrysophyllum albidum leaves and stem used against Pseudomonas aeruginosa, Staphylococcus aureus, Escherichia coli, Salmonella typhi, Klebsiella species, Bacillus subtilis, and Candida albicans were susceptible to plant ethanolic extract [21] [7].

Another research also reported that the aqueous extracts of the leave, stem, root and seed of Chrysophyllum albidum was used against Staphylococcus aureus, Escherichia coli, Pseudomonas aeruginosa Bacillus subtilis, Clostridium tetani and Candida albicans. It was reported that Chrysophyllum albidum stem and root extracts inhibited Staphylococcus aureus, Escherichia coli, Pseudomonas aeruginosa Bacillus subtilis, Clostridium tetani and Candida albicans ${ }^{[22]}$. The seed cotyledon only showed inhibition on Candida albicans, while the leaves did not inhibit any of these pathogens. Antimicrobial resistance is resistance of a microorganism to an antimicrobial drug to which it was originally sensitive. Resistant organisms (bacteria, fungi, viruses and some parasites) are able to stop the antimicrobial medicines from working, such as antibiotics, antifungals, antivirals and anti-malarials, so that standard treatments become ineffective and infections persists thereby increasing risk of spread to others ${ }^{[23]}$. It is the ability of a microorganism to withstand the effects of an antibiotic ${ }^{[24]}$.

Of note is the activity of Chrysophyllum albidum aqueous leave extract which inhibited all multi drug resistant organisms which was similar to a report by ${ }^{[25]}$, who reported that the lime oil (neat) showed a high antimicrobial activity against all organisms tested which include Pseudomonas aeruginosa, Staphylococcus aureus, Escherichia coli and Candida albicans.

The aqueous seed extract of Chrysophyllum albidum inhibited all the organisms tested except Enterococcus faecalis and Pseudomonas aeruginosa which were resistant. Methicillin Resistant Staphylococcus aureus had the lowest MIC of $128 \mu \mathrm{g} / \mathrm{ml}$.

The aqueous fruit extract of Chrysophyllum albidum did not inhibit Escherichia coli ATCC 25922, ESBL Escherichia coli, Shigella flexneri and Enterococcus faecalis.

However, Staphylococcus aureus, Pseudomonas aeruginosa and Methicillin Resistant Staphylococcus aureus had MIC of $64 \mu \mathrm{g} / \mathrm{ml}$ respectively. This is similar to the study by ${ }^{[30]}$, in which it was reported that the aqueous extract of lemon grass showed inhibition to Escherichia coli ATCC 25922, Shigella flexneri, Escherichia coli , and Salmonella paratyphi.

Notable in this study also was activity of Seamans Schnapps leaves extract on Shigella flexneri and Pseudomonas aeruginosa (MDR) 
which had MIC of $256 \mu \mathrm{g} / \mathrm{ml}$ and $64 \mu \mathrm{g} / \mathrm{ml}$ respectively showing the possibility of the extract as an agent that can be used in treating infections caused by Pseudomonas aeruginosa. This is similar to the report by ${ }^{[21]}$ where Pseudomonas aeruginosa, S.aureus, E.coli, and Klebsiella species were susceptible to the ethanolic leaf extract of C.albidum. Unlike the work by ${ }^{[22]}$, who reported that the ethanolic leaf extract showed no sensitivity to Pseudomonas aeruginosa. This may be due to the time of harvest of plants and age of plants [25]. Methicilin Resistant Staphylococcus aureus (MRSA), Shigella flexneri and Pseudomonas aeruginosa were the only organisms susceptible to the methanolic leaf extract. This supports the report of ${ }^{[20]}$ that S.aureus, E.coli, S.typhi and Shigella species were susceptible to aqueous extract and methanolic leaf extract of Chrysophyllum albidum unlike the work by ${ }^{[26]}$ on Albrus precatorius methanolic extract that showed no inhibition to Pseudomonas aeruginosa. This may be as a result of the difference in concentration and solvent for the extracts or time of collection or age of plant according to ${ }^{[31]}$. The minimum inhibitory concentration (MIC) of Chrysophyllum albidum Seaman's Schnapps fruit extracts varied with respect to the test organisms. At $32 \mu \mathrm{g} / \mathrm{ml}$ the growth of Klebsiella Pneumoniae was inhibited. At $64 \mu \mathrm{g} / \mathrm{ml}$ concentration, S.aureus (MRSA), E.coli (ESBL), Pseudomonas aeruginosa and Candida albicans were inhibited. At $512 \mu \mathrm{g} / \mathrm{ml}$, S.aureus (ATCC 25923), S.aureus, and Enterococcus feacalis were inhibited. Staphylococcus aureus was inhibited by the methanolic fruit extract which is similar to the work done by ${ }^{[26]}$ on methanolic extract of Abrus precatorius (L) fabaceae in which it was reported that Staphylococcus aureus was the most sensitive organism. [22] reported that only Candida albican showed inhibition to the aqueous seed extract of $\mathrm{C}$. albidum, however, this study showed inhibition of S.aureus, S.aureus (MRSA) and S.aureus ATCC 25923, E.coli, ESBL E.coli, Shigella flexneri, Klebsiella pneumonia and Candida albicans to the seed extract of Chrysophyllum albidum. This can be due to the age of leaves, time of harvesting and handling after harvesting ${ }^{[32]}$. Petroleum ether seed extract of Chrysophyllum albidum did not inhibit S.aureus, S.aureus (MRSA) and S.aureus ATCC 25923, although,it inhibited Shigella flexneri and
Enterococcus faecalis showing the oil of C. albidum has antimicrobial properties on some organisms. However, this is in contrast to ${ }^{[26]}$, where they reported that the seed oil extract of Abrus precatorius (L) Fabaceae was the most potent and had greater zones of inhibition against most of the Staphylococcus species used. The aqueous leaves extract in comparison to the aqueous fruit extract showed that the aqueous fruit extract had more antimicrobial potency than the leaves extract .Though the aqueous leaves extract inhibited all the tested organisms with MIC range between $128-512 \mu \mathrm{g} / \mathrm{ml}$, aqueous fruit extract with MIC range between $64-256 \mu \mathrm{g} / \mathrm{ml}$, was more potent in antimicrobial activities. This probably was due to time of harvesting and the use since plants from vegetative parts are less effective in therapy ${ }^{[33]}$.

Aqueous leaves inhibited all the tested organisms when compared with Seaman's Schnapps leaves extract which inhibited only Pseudomonas aeruginosa and Shigella flexneri which may be due to the solvents inability to extract the necessary ingredients or due to drug interaction ${ }^{[33]}$. Aqueous leaves extract of Chrysophyllum albidum inhibited all the tested organisms and has more active antimicrobial activities than Methanolic leaves extract which inhibited MRSA, Shigella flexneri and Pseudomonas aeruginosa different from the study by ${ }^{[26]}$ who reported that methanolic extract of Abrus precatorius(L) Fabaceae was more potent than Aqueous leave extract.

It is interesting to note that the Aqueous leaves extract and the Methanolic fruit extract both inhibited all the tested organisms, however, Methanolic fruit extract exhibited more antimicrobial potency against the tested organisms similar to the study by ${ }^{[26]}$. The methanolic leave and Petroleum ether seed extract of Chrysophyllum albidum has no antibacterial effect on Staphylococcus aureus and Escherichia coli which was in contrast to the methanolic seed extract of Daucus carota which showed antibacterial effect on the organisms as reported by ${ }^{\left[{ }^{34}\right.}$.The aqueous seed extract of Chrysophyllum albidum inhibited S.aureus, MRSA, E.coli, Shigella flexneri, Klebsiella pneumonia and Candida albicans which were similar to the studies by ${ }^{[35]}$ who reported that the ethanolic and methanolic seed extracts of Mangifera indica L (Mango) inhibited these 
organisms except Klebsiella pneumonia which was resistant.

The aqueous leave extract of Chrysophyllum albidum had antibacterial effect on S.aureus, E.coli, Shigella flexneri and Pseudomonas aeruginosa unlike studies by ${ }^{[36]}$ in which it was reported that the crude leaf extract of Mangifera indica Linn had no activity on these bacteria.

The methanolic crude extract of the fruit and leaves of Momordica charantia (Bitter melon) inhibited S.aureus, E.coli, Pseudomonas aeruginosa, Klebsiella pneumoniae and Candida albicans as reported by [37], which is similar to the result obtained with methanolic fruit extract of Chrysophyllum albidum in this study. ${ }^{[38]}$ reported that the aqueous extracts of Carrot, Amla and Pomegranate inhibited S.aureus, E.coli, Pseudomonas aeruginosa and Shigella flexneri which is similar to the result obtained with the aqueous leave extract of Chrysophyllum albidum in this study.

The result was different with the aqueous extract of Honey which inhibited Escherichi coli and Shigella flexneri. Aloe vera extract inhibited Escherichia coli, Pseudomonas aeruginosa and Shigella flexneri ${ }^{[38]}$.

The methanolic fruit extract of Chrysophyllum albidum inhibited all the organisms used in this study which was similar to the study by [39], who reported that the methanolic extract of Ocimumsanctum, Azadirachita indica and Phyllanthus amarus inhibited Staphylococcus aureus and Pseudomonas aeruginosa.

The lowest Minimum Inhibitory Concentration of $8 \mu \mathrm{g} / \mathrm{ml}$ was exhibited by the petroleum seed extract against Enterococcus faecalis, which was closely followed by methanolic fruit extract against Staphylococcus aureus while the Seaman's Schinapps fruit extract which had the lowest MIC of $32 \mu \mathrm{g} / \mathrm{ml}$ against Klebsiella pneumoniae which was similar to the study by ${ }^{[40]}$, who reported that all the organisms used including Klebsiella pneumonia were susceptible to the ethanolic extract of Unripe banana(Musa sapientum L).

The aqueous leaves extract shows more antimicrobial activities than the Seaman's Schinapps and methanolic leaves extracts. However, methanolic fruit extract was the best for the extraction of the active ingredients in
Chrysophyllum albidum because it inhibited all the tested organisms.

Methicillin Resistant Staphylococcus aureus is known to be of clinical importance due to its resistance pattern. The aqueous and methanolic leave extracts of Chrysophyllum albidum inhibited MRSA which was significant, except Seaman's Schnapps leaves and Petroleum ether seed extracts which showed resistant to the organism. A study by [26] showed that methanolic extract of Abrus precatorius (L) Fabaceae was more potent than aqueous leave extract.

Multi-drug resistance in Gram negative organisms is becoming a global threat and most available drugs are not active ${ }^{[9]}$. Chrysophyllum albidum had activity on these organisms and unlike studies by ${ }^{[36]}$, which had no activity on bacteria isolates.

\section{Conclusion}

This study revealed that Chyrsophyllum albidum leaves, fruits and seed extracts are active against Multidrug Resistant (MDR) organisms. Aqueous extract of Chrysophyllum albidum possess antimicrobial properties. Chyrsophyllum albidum is therefore recommended to be developed into new antimicrobials in readily available forms for use in Medical Microbiology Laboratory.

\section{References}

1. Ehiagbonare, JE,Onyibe, HI and Okoegwale, EE.(2008):Studies on the isolation of normal and abnormal seedlings of Chrysophyllum albidum: A step towards sustainable management of the taxon in the 21st Century. Scientific Research and Essay 3(12): 567-570.

2. Quattrocchi, U (2000): CRC World Dictionary of plant Names.IA-C. CRC Press.P.534 ISBN 978-0-8493-2675-2.

3. Madubuike, FN and Ogbonnaya, O (2003): The potential use of White Star Apple seed (Chrysophyllum albidum ) and physic Nut(Jatropha curcas) as feed ingredients for 
rats. Journal of Agricultural Science and Vetenery Medicine 1: 97-105.

4. Idowu, TO, Iwalewa, EO, Aderogba, MA, Akinpelu, BA and Ogundaini, $\mathrm{AO}(2006)$.Biochemical and behavioural effects of eleagnine from Chrysophyllumalbidum.Journal of Biological Sciences.6:1029-1034.

5. Akaneme, FI. (2008). Identification and preminary phytochemicalanalysis of herbs that can arrest threatened miscarriage in Orba andNsukka towns of Enugu State. African Journal of .Biotechnology.7:6-11.

6. Adebayo AH, Tan NH, Akindahunsi AA, Zeng GZ, Zhang YM. Anticancer and antiradical scavenging activity of Ageratum conyzoides L. (Asteraceae). Pharmacogn Mag 2010; 6(21): 62-66 [PMID: 20548938 PMCID: PMC2881656 DOI: 10.4103/0973-1296.59968]

7. Fasogbon SA, Okechi OO, Adisa JO, and Madukwe JU (2017): Immunohistochemical correlation between the expression of Vitamin D Receptor (VDR) and Triple negative Invasive ductal carcinoma tissues. $\boldsymbol{A m} . \boldsymbol{J}$. Biomed. $\quad$ Sci. $\quad 9(4): 237-243$; doi:10.5099/aj170400237

8. Sofowora, A(1993): Medicinal plants and traditional medicine in Africa. Spectrum books Ltd.

9. WHO, (2001): Author Traditional Medicine, factsheet

number134.2001.hpp/www.who.int/mediacentr efactsheet/fs/143

10. Aibinu, $\mathrm{I}, \quad$ Odugbemi, $\mathrm{T}$ and Brian,JM (2003).Extended- Spectrum Beta-Lactamase in Isolates of Klebsiella spp. and Escherichia coli fromLagos,Nigeria.Nigerian

Journal.Health.Biomedical Sciences. 2(2):5360.

11. Aibinu, I, Adenipekun, E and Odugbemi, $\mathrm{T}(2004)$ : Emergence of Quinolone Resistance amongst Escherichia coli strains isolated from clinicasl infectiouis in some Lagos State
Hospitals in Nigeria.Journal of Health and Biomedical Science.3(2):73-78.

12. Pretorius, JC, Magama, S, Zietsman, PC(2003). Growth Inhibition of plants pathogenic bacteria and fungi by extracts from selected South African plant species.South .African Journal of Biology.69(2):188-192.

13. Adisa, SA. (2000). Vitamin C, protein and mineral content of African Apple (Chrysophyllum albidum). In:Garba SA, Ijagbone IF, Iyagba AO, Iyame AO,Kilani AS, Ufaruna N. Proceeding of the $18^{\text {th }}$ annual conference of NIST (Eds.) pp.141-146.

14. Usha, K, Kasturi, GM and Hemalatha, P (2007): Hepatoprotective effect of hygrophila spinosa and Cassia occidentalis on carbon tetrachloride induced liver damage in experimental rats. India Journal of Clinical Biochemistry. 22(2):132-135.

15. Junaid, SA, Olabode, AO, Onwuliri, FC, Okwori, AEI and Agina, SE (2006): The antimicrobial properties of Ocimum gratissimum extracts on some selected bacterial gastrointestinal isolates. African Journal of Biotechnology. 5(22): 2315-2321.

16. Wichtl M. (2004). Herbal Drugs and Phytopharmaceuticals. Medpharm Scientific Publishers/CRC Press. pp.272-274.

17. Seaman, DR (2011): White willow Baerk, The oldest New Natural Anti inflammatory/Analgesic Agent. The American Chiropractor. 2011.

18. Alade PI, Irobi ON. Antimicrobial activities of crude leaf extracts of Acalypha wilkesiana. $\boldsymbol{J}$ Ethnopharmacol 1993; 39(3): 171-174 [PMID: 8258974]

19. Olukoya, D.K., Odugbemi, T.O. and Bamigbose, D.O.A. (1986).Some aspect of traditional therapy of Gonorrhea in Lagos,Nigeria, Journal of Research in EthnoMedicine.1:26-29. 
20. Duyilemi, OP and Lawal, IO (2009) Antibacterial activity and phytochemical screening of Chrysophyllum albidum leaves.AsianJournal of Food and Agro Industry. 2:75-79

21. Kamba, AS and Hassan, LG (2011).Phytochemical screening and antimicrobial activities of African star Apple (Chrysophyllum albidum) leaves,stem against some pathogenic microorganisms. International Journal of Pharmaceutical Frontier Research.1 (2):119-129

22. Okoli, BJ and Okere, OS (2010): Antimicrobial activity of the Phytochemical constituents of Chrysophyllum albidum G.Don_Holl. (African Star Apple) plant: Journal of Research in National Development. 8 (1):1035-1037.

23. WHO, (2011):World Health Organization, World Health day 2011. (www.who.int/worldhealth-day/2011/world -health -day2011brochure.pdf).

24. Todar, K.(2001) Todar's Online of Bacteriology $1^{\text {st }} \quad$ Edition, University of Wisconsium,Madison, $\boldsymbol{U S A}$,pp.870

25. Aibinu I, Adenipekun $\mathrm{T}$, Adelowotan $\mathrm{T}$, Ogunsanya T, Odugbemi T. Evaluation of the antimicrobial properties of different parts of Citrus aurantifolia (lime fruit) as used locally. Afr J Tradit Complement Altern Med 2006; 4(2): 185-190 [PMID: 20162090 PMCID: PMC2816438]

26. Adelowotan O, Aibinu I, Adenipekun E, Odugbemi T. The in-vitro antimicrobial activity of Abrus precatorius (L) fabaceae extract on some clinical pathogens. Niger Postgrad Med J 2008; 15(1): 32-37 [PMID: 18408781]

27. Amaeze OU, Ayoola GA, Sofidiya MO, Adepoju-Bello AA, Adegoke AO, Coker HA. Evaluation of antioxidant activity of Tetracarpidium conophorum (Mull. Arg) Hutch \& Dalziel leaves. Oxid Med Cell Longev 2011; 2011: 976701 [PMID: 21912723 PMCID: $\quad$ PMC3168771 DOI: $\underline{10.1155 / 2011 / 976701]}$
28. Bonjar S. Evaluation of antibacterial properties of some medicinal plants used in Iran. $\boldsymbol{J}$ Ethnopharmacol 2004; 94(2-3): 301-305 [PMID: 15325735 DOI: 10.1016/j.jep.2004.06.007]

29. Prescott,ML, John, P, Harley, D and Klein, A(1999) Antimicrobial chemotherapy in

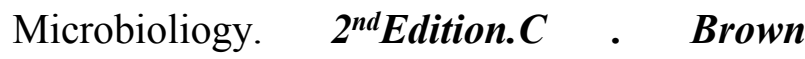
publishers $\mathrm{p} 328$.

30. Fagbemi, Josephine F.; Ugoji E.; Adenipekun T.; and Adelowotan, O. (2009): Evaluation of the antimicrobial properties of unripe banana, lemon grass, and turmeric on pathogen. African Journal of Biotechnology, 8(7), 11761182.

31. Odugbemi TO, Akinsulire OR, Aibinu IE, Fabeku PO. Medicinal plants useful for malaria therapy in Okeigbo, Ondo State, Southwest Nigeria. Afr J Tradit Complement Altern Med 2006; 4(2): 191-198 [PMID: 20162091 PMCID: PMC2816451]

32. Aibinu, I. (2006): Medicinal plants as antimicrobials' In:Odugbemi, $\boldsymbol{T}$ Outline and pictures of medicinal plants from Nigeria. University of Lagos press.pp.53-64.

33. Aibinu, I, Adenipekun, E and Adelowotan, TO (2008). 'Factors that may be responsible for the ineffectiveness of medicinal plants when used in therapy'.In :Odugbemi Tolu.A Textbook of Medicinal Plants from Nigeria.pp319-323.

34. Kumarasamy Y, Nahar L, Byres M, Delazar A, Sarker SD. The assessment of biological activities associated with the major constituents of the methanol extract of 'wild carrot' (Daucus carota L) seeds. J Herb Pharmacother 2005; 5(1): 61-72 [PMID: 16093236]

35. Awad El-Gied AA, Abdelkareem AM, Hamedelniel EI. Investigation of cream and ointment on antimicrobial activity of Mangifera indica extract. J Adv Pharm Technol Res 2015; 6(2): 53-57 [PMID: 
25878974 PMCID: PMC4397619 DOI: $\underline{10.4103 / 2231-4040.154530]}$

36. Doughari, JH and Manzara, S (2008).In Vitro antibacterial activity of crude leaf extracts of Mangifera indicaLinn. African

JournalofMicrobiology Research 2:67-72.

37. Mwambete KD. The in vitro antimicrobial activity of fruit and leaf crude extracts of Momordica charantia: a Tanzania medicinal plant. Afr Health Sci 2009; 9(1): 34-39 [PMID: 20842240 PMCID: PMC2932517]

38. Jeswin, P, Shella, J and Priya I(2012):Antimicrobial activities of Aloevera Barbedensis, Daucus carota, Emblica officinalis, Honey and Punicagranatum and Formulation of Health Drink and Salad.
Malaysian Journal of Microbiology.8(3): 141147

39. Saranraj, P., Bharathi, T and Kolanjinathan, K (2014):Antimicrobial Activity of solvent extracts of Ocimum sanctum, Azadirachta indica and Phyllanthus amarus against clinical Pathogens. Global Journal of Pharmacology, 8 (3): 294-305.

40. Ugoji, E, Adenipekun, $\mathrm{T}$ and Adelowotan, O (2009): Evaluation of the antimicrobial properties of Unripe banana(Musa sapientum L), Lemon grass (Cymbopogon citratus S) and turmeric (Curcuma longa L) on Pathogens.African Journal

Biotechnology. 8 (7):1176-1182 